\title{
Ocular Pathologies in Children with Mental Retardation: A Prospective Study
}

\author{
Zihinsel Engelli Çocuklarda Oküler Patolojiler: Prospektif Bir Çalışma
}

\author{
Nurdan ARICAN 1 \\ (1) 0000-0003-3311-7857 \\ Murat TUNÇ ${ }^{2}$ \\ (D) 0000-0002-2331-2483
}

${ }^{1}$ Düzce Atatürk State Hospital, Ophthalmology Clinic, Düzce, Turkey ${ }^{2}$ Private Tunç Eye Diseases Clinic, Ankara, Turkey

\section{Corresponding Author Sorumlu Yazar \\ Nurdan ARICAN \\ nurdanbsb@hotmail.com}

Received / Geliş Tarihi : 31.08 .2020 Accepted / Kabul Tarihi : 27.11.2020 Available Online /

Çevrimiçi Yayın Tarihi : 25.12.2020

\begin{abstract}
Aim: The aim of this study is to investigate the ocular pathologies in mentally retarded pediatric patients without Down syndrome or any certain chromosomal-genetic anomaly. Material and Methods: A total of 189 patients, including 79 mental retarded and 110 healthy children, were included in this study between 2010 and 2011. Demographic factors (age, gender) of the patients, and affected side, visual acuity, esotropia, exotropia, anterior segment pathologies and posterior segment pathologies were evaluated. All pediatric patients in study group were divided as IQ level $<34,35-49,50-69$, and $>70$ according to Wechsler Intelligence Scale for Children-Revised Form.

Results: The mean age of the children with mental retardation was $11.85 \pm 6.19$ (3-17) years, while the mean age of healthy children was $10.73 \pm 3.35$ (3-15) years. While visual impairment was present in 8 of the 74 patients whose vision was evaluated, there was no impairment in the healthy group $(\mathrm{p}=0.001$ and $\mathrm{p}=0.004$ for right and left, respectively). Anterior segment pathology was detected in $2(2.5 \%)$ cases, and posterior segment pathology in $3(3.8 \%)$ cases in children with low IQ. While strabismus was detected in $7(8.9 \%)$ patients with low IQ, no strabismus was found in healthy children. Five $(6.3 \%)$ of the cases with mental retardation had exotropia and $2(2.5 \%)$ had esotropia. Exotropia was found significantly higher in children with mental retardation compared to the control group $(\mathrm{p}=0.012)$.

Conclusion: Visual impairment, anterior-posterior segment pathology, exotropia had a high prevalence in children with mental retardation, and all ocular pathologies were related to low intellectual disability.

Keywords: Children; mentally retarded; vision disorders.
\end{abstract}

\section{ÖZ}

Amaç: $\mathrm{Bu}$ çalışmanın amacı Down sendromu veya herhangi bir kromozomal-genetik anomalisi olmayan zihinsel engelli pediatrik hastalarda oküler patolojilerin araştııılmasıdır.

Gereç ve Yöntemler: Bu çalışmaya 2010 ve 2011 yılları arasında 79 zeka geriliği olan ve 110 sağlıklı çocuk olmak üzere toplam 189 hasta dahil edildi. Hastaların demografik faktörleri (yaş, cinsiyet) ile etkilenen taraf, görme keskinliği, ezotropya, ekzotropya, ön segment patolojileri ve arka segment patolojileri değerlendirildi. Çalışma grubundaki tüm pediatrik hastalar Wechsler Çocuklar için Zeka Ölçeği-Yenilenmiş Formu'na göre IQ düzeyi <34, 35-49, 50-69 ve $>70$ olarak ayrild1.

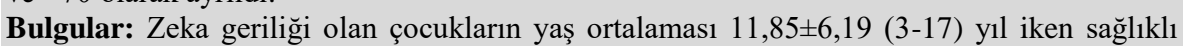
çocukların yaş ortalaması 10,73 $\pm 3,35$ (3-15) yıl idi. Görmesi değerlendirilen 74 hastanın 8 'inde görme bozukluğu varken, sağlıklı grupta ise hiç görme bozukluğu yoktu (sağ ve sol için sırasıly $\mathrm{p}=0,001$ ve $\mathrm{p}=0,004)$. Düşük IQ'lu çocuklarda, $2(\% 2,5)$ olguda ön segment patolojisi ve $3(\% 3,8)$ olguda ise arka segment patolojisi saptandı. Düşük IQ'lu hastaların $7(\% 8,9)$ 'sinde şaşılık saptanırken sağlıklı çocuklarda ise hiç şaşılık saptanmadı. Zeka geriliği olan olguların $5(\% 6,3)$ 'inde ekzotropya, $2(\% 2,5)$ 'sinde ise ezotropya vardı. Ekzotropya zeka geriliği olan çocuklarda kontrol grubuna göre anlamlı derecede daha yüksek olarak bulundu $(\mathrm{p}=0,012)$.

Sonuç: Zihinsel engelli çocuklarda görme bozukluğu, ön-arka segment patolojisi, ekzotropya yüksek prevalansa sahipti ve tüm oküler patolojiler düşük zihinsel engelle ilişkiliydi.

Anahtar kelimeler: Çocuk; zihinsel özürlü; görme bozuklukları. 


\section{INTRODUCTION}

Mental retardation is defined by low intellectual (intelligence quotient, IQ <75) functioning and is accompanied by many ocular findings, including pathologies of the anterior and posterior ocular segments, as strabismus, refractive errors, visual acuity (1-4). The incidence of each ocular abnormality varies in different studies (5-7). Sauer et al. (7) examined the refractive errors and ocular pathologies between newborn and children with severe behavioral pathologies and developmental disabilities. The authors studied a retrospective review of ocular examinations that 222 children between the ages of 0 and 4 (mean 2.2 \pm 0.9 ) years were performed and 100 $(45.0 \%)$ had an ocular abnormality. They resulted that the frequency of ocular abnormality was $33.3 \%$, strabismus was $10.9 \%$, and nystagmus was $12.2 \%$. In addition, they demonstrated that ophthalmic pathologies are most frequent even at a young age in children with behavioral pathologies and developmental disorders (8). And also, most visual pathologies in children with retarded intellectual development can be treated; early diagnosis and intervention can have a lifelong positive effect on neurodevelopment $(9,10)$. Adults with mental retardation have a significantly higher rate of pathological ocular findings compared to the healthy population $(11,12)$. Similarly, children with mental retardation are twice more likely to have abnormal eye findings than healthy children (13). Causes of mental retardation can be examined in two main groups; first, chromosomal disorders, genetic syndromes and second ones whose causes are not fully determined (4). In Turkey, the mentally retarded in $60 \%$ of patients in a study conducted in patients with a genetic-chromosomal disorder was detected, in $40 \%$, no specific cause could be determined $(2,3)$. The aim of this study was to investigate the ocular findings in mentally retarded patients without Down syndrome or any certain chromosomal-genetic anomaly. In this current study, we studied ocular findings in children with mentally retardation and compared the results with healthy children.

\section{MATERIAL AND METHODS}

Between October 2010 and December 2011, 189 patients who met the inclusion criteria out of 200 patients $(90$ mentally retarded, 110 healthy) aged 0-18 years who applied to Duzce University Faculty of Medicine ophthalmology clinic with the diagnosis of motor or mental developmental retardation or for special education were included in the study. A prospective comparative evaluation was made in terms of routine ocular examination and strabismus.

This study was approved by the Duzce University Faculty of Medicine non-invasive health research ethics committee (2010/66), and all patients were informed about the study, informed consent form and ethical approval were obtained. Patients with IQ level of 75 and below were included in the study group, while patients with Down syndrome $(n=4)$ and diagnosed chromosomal genetic anomaly $(n=7)$ were excluded from the study. Patients with normal intelligence (IQ >80) who applied to a healthy pediatric outpatient clinic were included in the control group. In this study, a total of 189 patients, including 79 mental retarded and 110 healthy children were included.
The results of a complete ocular examination by a strabismus specialist including pattern and size of eye deviation, visual acuity, refractive errors and presence or absence of amblyopia was evaluated. Age and gender as the demographic factors of the patients, and affected side, visual acuity, esotropia, exotropia, anterior segment pathologies and posterior segment pathologies were evaluated. An autorefractor (Nikon Retinomax K-plus; Nikon, Melville, NY, USA) was used for refractive errors with in cycloplegia (30 mins after cyclopentolate 1\%), in addition esotrophia and exotropia was evaluated using Hirschberg's test. All pediatric patients in study group were divided as IQ <34 ( $n=4)$, IQ 35-49 ( $n=20)$, IQ 50-69 $(n=54), I Q>70 \quad(n=1)$ according to Wechsler Intelligence Scale for Children-Revised Form (WISC-R).

\section{Statistical Analysis}

Statistical analyzes were performed using the number cruncher statistical system (NCSS) 2007 statistical software. In the evaluation of the data, in addition to descriptive statistical methods (mean, standard deviation), the distribution of variables was examined with the Kolmogorov-Smirnov normality test. Independent samples $\mathrm{t}$ test for comparison of groups in terms of normally distributed variables and also Chi-square and Fisher's exact tests were used for comparisons of qualitative data. The results were evaluated at the significance level of $<0.05$.

\section{RESULTS}

Seventy nine children (44 male, 35 female) with mental retardation (IQ <75) and 110 healthy children $(62$ males, 48 female) were included in this study. The mean age of children with mental retardation was $11.85 \pm 6.19(3-17)$ years, while the mean age of healthy children was $10.73 \pm 3.35$ (3-15) years. No statistically significant difference was observed between the mean age and gender distribution of both groups $(\mathrm{p}=0.111, \mathrm{p}=0.927)$. When mental retardation was examined by IQ level, 1 patient had mild (IQ >70), 54 patients had moderate (IQ =50-69), 20 patients had severe (IQ $=35-49)$, and 4 patients had very severe (IQ <34) IQ level.

In 5 patients with low IQ, the visual level could not be determined because they could not be cooperated. While visual impairment was present in 8 of the 74 patients whose vision was evaluated, there was no impairment in the healthy group ( $p=0.001$ and $p=0.004$ for right and left, respectively). While anterior segment pathology was detected in $2(2.5 \%)$ cases in children with low IQ, cataracts and other anterior segment pathologies were not found in the healthy group $(\mathrm{p}=0.173)$. In cases with low IQ, 1 patient had advanced myopia, 1 patient had optic atrophy and 1 patient had chorioretinal degeneration, while no posterior segment pathology was found in the healthy group ( $\mathrm{p}=0.071$ both right and left). While strabismus was detected in $7(8.9 \%)$ patients with low IQ, no strabismus was found in healthy children. Five $(6.3 \%)$ of the cases with mental retardation had exotropia and $2(2.5 \%)$ had esotropia. Exotropia was found significantly higher in children with mental retardation compared to the control group $(\mathrm{p}=0.012)$. In terms of esotropia, no significant difference was found between children with mental retardation and the control group $(\mathrm{p}=0.173$, Table 1,2$)$. 
Table 1. Comparison of MR and control groups

\begin{tabular}{lccc}
\hline & $\begin{array}{c}\text { Control } \\
(\mathbf{n = 1 1 0})\end{array}$ & $\begin{array}{c}\text { MR } \\
(\mathbf{n = 7 9})\end{array}$ & $\mathbf{p}$ \\
\hline Age (years), mean \pm SD & $10.73 \pm 3.35$ & $11.85 \pm 6.19$ & $0.111^{*}$ \\
$\begin{array}{l}\text { Gender, n (\%) } \\
\quad \text { Male }\end{array}$ & $62(56.4)$ & $44(55.7)$ & $0.927^{\#}$ \\
$\quad$ Female & $48(43.6)$ & $35(44.3)$ & \\
Exotropia & $0(0.0)$ & $5(6.3)$ & $\mathbf{0 . 0 1 2}^{\ddagger}$ \\
Esotropia & $0(0.0)$ & $2(2.5)$ & $0.173^{\ddagger}$ \\
Visual Acuity (R) & $0(0.0)$ & $8(10.1)$ & $\mathbf{0 . 0 0 1}^{\ddagger}$ \\
Visual Acuity (L) & $0(0.0)$ & $6(7.6)$ & $\mathbf{0 . 0 0 4}^{\ddagger}$ \\
Anterior segment (R) & $0(0.0)$ & $2(2.5)$ & $0.173^{\ddagger}$ \\
Anterior segment (L) & $0(0.0)$ & $2(2.5)$ & $0.173^{\ddagger}$ \\
Posterior segment (R) & $0(0.0)$ & $3(3.8)$ & $0.071^{\ddagger}$ \\
Posterior segment (L) & $0(0.0)$ & $3(3.8)$ & $0.071^{\ddagger}$ \\
\hline MR: mental retardation, SD: standard ${ }^{\ddagger}$ deviation, R: right L : left, ${ }^{*}:$ Independent
\end{tabular}

MR: mental retardation, SD: standard deviation, R: right, L: left, " : Independent samples t test, ": Chi square test, ${ }^{\ddagger}:$ Fisher's exact test

Table 2. Ocular pathologies by IQ level in children with mental retardation

\begin{tabular}{lcccc}
\hline & $\begin{array}{c}<\mathbf{3 4} \\
(\mathbf{n = 4})\end{array}$ & $\begin{array}{c}\mathbf{3 5 - 4 9} \\
(\mathbf{n = 2 0})\end{array}$ & $\begin{array}{c}\mathbf{5 0 - 6 9} \\
(\mathbf{n = 5 4})\end{array}$ & $\begin{array}{c}>70 \\
(\mathbf{n = 1})\end{array}$ \\
\hline $\begin{array}{l}\text { Gender, n (\%) } \\
\quad \text { Male }\end{array}$ & $4(100)$ & $11(55.0)$ & $29(53.7)$ & $0(0.0)$ \\
$\quad$ Female & $0(0.0)$ & $9(45.0)$ & $25(46.3)$ & $1(100)$ \\
Exotropia & $0(0.0)$ & $1(5.0)$ & $4(7.4)$ & $0(0.0)$ \\
Esotropia & $1(25.0)$ & $0(0.0)$ & $1(1.9)$ & $0(0.0)$ \\
Visual Acuity (R) & $1(25.0)$ & $1(5.0)$ & $5(9.3)$ & $1(100)$ \\
Visual Acuity (L) & $1(25.0)$ & $1(5.0)$ & $3(5.6)$ & $1(100)$ \\
Anterior segment (R) & $1(25.0)$ & $1(5.0)$ & $0(0.0)$ & $0(0.0)$ \\
Anterior segment (L) & $1(25.0)$ & $1(5.0)$ & $0(0.0)$ & $0(0.0)$ \\
Posterior segment (R) & $1(25.0)$ & $1(5.0)$ & $1(1.9)$ & $0(0.0)$ \\
Posterior segment (L) & $1(25.0)$ & $1(5.0)$ & $1(1.9)$ & $0(0.0)$ \\
\hline IQ: intelligence quotient, MR: mental retardation, R: right, L: left
\end{tabular}

IQ: intelligence quotient, MR: mental retardation, R: right, L: left

\section{DISCUSSION}

We present ocular pathology in children with mentally retardation and compared the results with healthy children in this current prospective study. We resulted that refractive errors, anterior-posterior segment pathology and strabismus (especially exotropia) were most frequently seen in mentally retarded children than healthy.

In mental retardation, there is a slow growing development of intelligence, affecting all cognitive abilities (14). Accordingly, children with mental retardation experience deficiencies in social activities such as communication, self-management, social skills, self-care, using social resources and ensuring their personal safety (15). Behavioral research has shown that the impact of visual impairment on early development is profound, and early in life, visually impaired children begin to lag behind children who see developmentally similar (2). Adults with mental retardation have a higher rate of refractive errors and ocular pathologies compared to the general population $(13,16)$. Similarly, children with mental retardation are twice as likely to have ocular pathology than healthy children (17,18). Akinci et al. (17) evaluated the ophthalmological findings in children with intellectual disability and in controls of mean intellectual development. The authors compared 724 cases with intellectual disability and 151 control children in their study. They demonstrated that increasing severity of intellectual disability was related to higher prevalence of nystagmus, strabismus, astigmatism, hypermetropia, and anisometropia. In addition they resulted that in children with moderate, severe and syndromic mental retardation, evaluation and treatment of eye findings are important in reducing future health and social care costs and improving their productive lives. In another study, Aslan et al. (18) examined 215 children with mental disabilities (90 Down syndrome, 125 nonprofound ID) and 116 healthy cases for causeless preventable visual impairment in mentally retarded children. The authors resulted that the children with intellectual disability has a high prevalence of preventable visual impairments, refractive errors, strabismus, and cataracts.

In cases of mental retardation not related to a prominent chromosomal genetic disorder such as Down syndrome in etiology, the incidence of strabismus was found to be significantly higher than in healthy children (19). In terms of the direction of strabismus, exotropia is more common than esotropia. Our study and some other series show that strabismus can be seen more in mental retardation than in the normal population $(20,21)$. Sandfeld Nielsen et al. (20) studied that prevalence of refractive errors and strabismus in children with developmental delay. The authors examined 923 children with IQ $\leq 80$, aged between 4-15 years in their study. They showed that strabismus was found in $26.8 \%$ of subjects (esotropia in $14.9 \%$, exotropia in $10.3 \%$, and other forms, including mixed types, in $1.6 \%)$. As a result, strabismus was significantly correlated with low IQ. In addition, there are case series reporting the incidence of strabismus of $40 \%$ or more in mentally retarded cases $(15,16)$.

Exotropia was significantly more common in cases with mental retardation in our study. Similarly, there are studies emphasizing that exotropia is more common in mentally disabled people (21), as well as publications reporting that esotropia is more common $(20,22)$. Gogate et al. (21) examined that results of horizontal strabismus surgery. The authors studied 529 children 9 years in their study. They showed that exotropia was most often than esotropia in children. On the other hand, Donnelly et al. (22) studied that the prevalence of childhood visual disorders: amblyopia (strabismus, refractive errors) and organic disease. The authors studied 1582 children aged 8-9 years in their study. They resulted that 198 children (12.5\%) had a significant visual disorder: strabismus (3.98\%), eso:exo rate 5:1, anisometropia (2.34\%), ametropia (5.82\%), organic defects $(0.38 \%)$. It is noteworthy that esotropia is more common in Down syndrome cases $(19,23)$. Exclusion of Down syndrome and cases with other chromosomal anomalies in our study may play a role in the detection of exotropia more frequently.

There are a few limitations in this current study. First, the number of patients was relatively small. Children with syndromic mental retardation could be included in our study and compared with non-syndromic and healthy children. Further prospective-multicenter studies with large number of patients are needed. 


\section{CONCLUSION}

There is already a difficulty in communicative and social skills in children with mental retardation. Strabismus can complicate the social adaptation of the child, as it can increase negative social pressure on the child. Removing cosmetic or visual ocular problems can facilitate social adaptation by reducing social pressure in children with mental retardation.

Ethics Committee Approval: The study was approved by the Ethics Committee of Düzce University Faculty of Medicine (30.09.2010, 66).

Conflict of Interest: None declared by the authors.

Financial Disclosure: None declared by the authors.

Acknowledgements: None declared by the authors.

\section{REFERENCES}

1. Tuppurainen K. Ocular findings among mentally retarded children in Finland. Acta Ophthalmol (Copenh). 1983;61(4):634-44.

2. Tsao WS, Hsieh HP, Chuang YT, Sheu MM. Ophthalmologic abnormalities among students with cognitive impairment in eastern Taiwan: The special group with undetected visual impairment. J Formos Med Assoc. 2017;116(5):345-50.

3. Chang YS, Shih MH, Tseng SH, Cheng HC, Teng CL. Ophthalmologic abnormalities in high school students with mental retardation in Taiwan. J Formos Med Assoc. 2005;104(8):578-84.

4. Lennerstrand G, Axelsson A, Andersson G. Visual assessment with preferential looking techniques in mentally retarded children. Acta Ophthalmol (Copenh). 1983;61(2):183-5.

5. Jamali P, Fotouhi A, Hashemi H, Younesian M, Jafari A. Refractive errors and amblyopia in children entering school: Shahrood, Iran. Optom Vis Sci. 2009;86(4):364-9.

6. Robaei D, Rose K, Ojaimi E, Kifley A, Huynh S, Mitchell P. Visual acuity and the causes of visual loss in a population-based sample of 6-year-old Australian children. Ophthalmology. 2005;112(7):1275-82.

7. Afsari S, Rose KA, Gole GA, Philip K, Leone JF, French A, et al. Prevalence of anisometropia and its association with refractive error and amblyopia in preschool children. Br J Ophthalmol. 2013;97(9):10959.

8. Sauer T, Lawrence L, Mayo-Ortega L, Oyama-Ganiko R, Schroeder S. Refractive error and ocular findings among infants and young children with severe problem behavior and developmental disabilities. J Ment Health Res Intellect Disabil. 2018;11(4):251-65.

9. Ghising R, Shakya S, Rizyal A, Shrestha R, Shrestha $\mathrm{S}$, Wang-Harris $\mathrm{S}$. Prevalence of refractive error in mentally retarded students of Kathmandu Valley. Nepal Med Coll J. 2007;9(4):262-5.

10. Woodruff ME. Prevalence of visual and ocular anomalies in 168 non-institutionalized mentally retarded children. Can J Public Health. 1977;68(3):225-32.

11. Mwanza JC, Nkidiaka CM, Kayembe DL, Maillet CY, Mukau EJ, Tuela MR. Ophthalmologic abnormalities in mentally retarded. Bull Soc Belge Ophtalmol. 2000;(277):75-8.

12. Ljubic A, Trajkovski V. Refractive errors in children and young adults with Down's syndrome. Acta Ophthalmol. 2011;89(4):324-7.

13. Saw SM, Tan SB, Fung D, Chia KS, Koh D, Tan DT, et al. IQ and the association with myopia in children. Invest Ophthalmol Vis Sci. 2004;45(9):2943-8.

14. Gogate P, Soneji FR, Kharat J, Dulera H, Deshpande M, Gilbert C. Ocular disorders in children with learning disabilities in special education schools of Pune, India. Indian J Ophthalmol. 2011;59(3):223-8.

15. van Isterdael CE, Stilma JS, Bezemer PD, Tijmes NT. 6,220 institutionalised people with intellectual disability referred for visual assessment between 1993 and 2003: overview and trends. $\mathrm{Br} \mathrm{J}$ Ophthalmol. 2006;90(10):1297-303.

16. McCulloch DL, Sludden PA, McKeown K, Kerr A. Vision care requirements among intellectually disabled adults: a residence-based pilot study. J Intellect Disabil Res. 1996;40(Pt 2):140-50.

17. Akinci A, Oner O, Bozkurt OH, Guven A, Degerliyurt A, Munir K. Refractive errors and ocular findings in children with intellectual disability: a controlled study. J AAPOS. 2008;12(5):477-81.

18. Aslan L, Aslankurt M, Aksoy A, Altun H. Preventable visual impairment in children with nonprofound intellectual disability. Eur J Ophthalmol. 2013;23(6):870-5.

19. Ljubic A, Trajkovski V, Stankovic B. Strabismus, refractive errors and nystagmus in children and young adults with Down syndrome. Ophthalmic Genet. 2011;32(4):204-11.

20. Sandfeld Nielsen L, Skov L, Jensen H. Visual dysfunctions and ocular disorders in children with developmental delay. II. Aspects of refractive errors, strabismus and contrast sensitivity. Acta Ophthalmol Scand. 2007;85(4):419-26.

21. Gogate PM, Rishikeshi N, Taras S, Aghor M, Deshpande MD. Clinical audit of horizontal strabismus surgery in children in Maharashtra, India. Strabismus. 2010;18(1):13-7.

22. Donnelly UM, Stewart NM, Hollinger M. Prevalence and outcomes of childhood visual disorders. Ophthalmic Epidemiol. 2005;12(4):243-50.

23. Berk AT, Saatci AO, Erçal MD, Tunç M, Ergin M. Ocular findings in 55 patients with Down's syndrome. Ophthalmic Genet. 1996;17(1):15-9. 